\title{
Efektivitas Ekstrak Bawang Merah (Allium ascalonicum L) Terhadap Penurunan Suhu Tubuh Anak dengan
} Demam Pasca Imunisasi DPT Pentabio

\author{
Setiawandari \\ Prodi Studi Sarjana Kebidanan, Fakultas Sains Kesehatan, Universitas PGRI Adi Buana Surabaya, \\ setiawandari7@gmail.com (koresponden) \\ Eka DevianyWidyawaty \\ Prodi Studi D-III Kebidanan, Akademi Kebidanan Wijaya Kusuma Malang, ekadeviany719@gmail.com
}

\begin{abstract}
The immunizations that must be given to children include the Diphtheria Pertussis Tetatus-Hepatitis BHemophilus Influenza type B vaccine or better known as Pentabio DPT. The DTwP / HB / HiB vaccine is given to babies in 3 doses at 1 month intervals. This immunization caused a systemic reaction, one of which was a fever of $0.85 \%$ in the first 30 minutes and increased to $14.03 \%$ on the day after immunization. The purpose of this study was to determine the effectiveness of shallots (Allium ascalonicum L) in reducing the body temperature of feverish children after Pentabio DPT immunization. This type of research was quasiexperimental study, with pre and post test with control group design. The sample in this study were babies who received DPT immunization as many as 20 respondents. DPT Pentabio immunization was given a dose of $0.5 \mathrm{ml}$ in the intervention group and the control group. The statistical test used was the T test. The results showed that there was a significant effect of shallots on in reducing the body temperature offeverish children after Pentabio DPT immunization, with a p-value of 0.000 .
\end{abstract}

Keywords: shallots; body temperature; fever; Pentabio DPT immunization

ABSTRAK

Imunisasi yang wajib diberikan kepada anak-anak diantaranya adalah vaksin Diphtheria Pertusis TetatusHepatitis B-Hemophilus Influenza type B atau lebih dikenal dengan DPT Pentabio. Vaksin DTwP/HB/HiB diberikan kepada bayi sebanyak 3 dosis dengan interval 1 bulan. Imunisasi ini menimbulkan reaksi sistemik salah satunya berupa demam $0,85 \%$ pada 30 menit pertama dan meningkat menjadi $14,03 \%$ pada satu hari pasca imunisasi. Tujuan dari penelitian ini adalah mengetahui efektifitas bawang merah (Allium ascalonicum L) terhadap penurunan suhu tubuh anak demam pasca imunisasi DPT Pentabio. Jenis penelitian quasi eksperimen dengan pre and post test with control group design. Sampel pada penelitian ini adalah bayi yang mendapat imunisasi DPT sebanyak 20 orang responden. Pemberian imunisasi DPT PENTABIO Pentabio dosis 0,5 ml pada kelompok intervensi dan kelompok kontrol. Uji statistik yang digunakan adalah Uji T. Hasil penelitian menunjukkan ada pengaruh yang signifikan dari bawang merah dalam menurunkan suhu tubuh anak demam pasca imunisasi DPT Pentabio, dengan $p$-value 0,000 .

Kata kunci: bawang merah; suhu tubuh; demam; imunisasi DPT Pentabio

\section{PENDAHULUAN}

Imunisasi adalah suatu upaya untuk menimbulkan atau meningkatkan seseorang secara aktif terhadap suatu penyakit, sehingga bila suatu saat terpajan dengan penyakit tersebut tidak akan sakit atau hanya mengalami sakit ringan. Imunisasi yang wajib diberikan kepada anak-anak diantaranya adalah vaksin Diphtheria Pertusis Tetatus-Hepatitis B-Hemophilus Influenza type B atau lebih dikenal dengan DPT Pentabio. Vaksin DTwP/HB/HiB diberikan kepada bayi sebanyak 3 dosis dengan interval 1 bulan untuk mencegah penyakit Diphtheria Pertusis Tetatus-Hepatitis B-Hemophilus Influenza type B. Vaksin adalah antigen berupa mikroorganisme yang sudah mati atau mikroorganisme hidup yang dilemahkan, yang telah diolah menjadi toksoid, protein rekombinan yang bila diberikan kepada seseorang akan menimbulkan kekebalan spesifik secara aktif terhadap penyakit infeksi tertentu. Oleh karena itu akan ada kejadian medik yang berkaitan dengan imunisasi baik berupa efek vaksin ataupun efek simpang, toksisitas, reaksi sensitifitas, efek farmakologis maupun kesalahan program, koinsidens, reaksi suntikan atau hubungan kausal yang tidak dapat ditentukan yang disebut dengan Kejadian Ikutan Pasca Imunisasi (KIPI). ${ }^{(1)}$

Berdasarkan hasil penelitian yang dilakukan oleh Julitasari Sundoro, dkk tahun 2017 tentang profil keamanan setelah pemberian dosis primer vaksin Pentabio pada bayi di Indonesia bahwa reaksi sistemik yang paling banyak timbul adalah demam $0,85 \%$ pada 30 menit pertama dan meningkat menjadi 14,03\% pada satu hari pasca imunisasi. Sedangkan reaksi local yang timbul adalah nyeri pada tempat suntikan $67,6 \%$ pada 30 
menit setelah imunisasi dan meningkat menjadi $87,23 \%$ pada satu hari pascaimunisasi, mayoritas nyeri yang timbul adalah katagori nyeri ringan.

Sesuai hasil studi pendahuluan di PMB Istiqomah Surabaya diketahui bahwa bayi yang demam pasca imunisasi DPT Pentabio adalah sekitar $20 \%$ dan bayi yang mendapati keluhan nyeri pada tempat suntikan sekitar $45 \%$.

Cara untuk menurunkan demam pasca imunisasi DPT Pentabio pada anak selama ini adalah dengan pemberian terapi farmakologi yaitu sirup antipirektik (sirup parasetamol). Meskipun syrup parasetamol relative aman tetapi tetap memiliki efek samping seperti hepatotoksisitas, nekrosis hepar yang fatal, nekrosis tubular ginjal dan koma hipoglikemik pada penggunaan jangka panjang dengan dosis yang berlebihan. ${ }^{(3)}$

Bawang merah (Allium cepa varietas ascalonicum) dapat digunakan sebagai penganti kompres panas pada anak demam. Kandungan senyawa sulfur organic yaitu Allylcysteine Sulfoxida (Alliin) dapat menurunkan demam dengan mekanisme menghancurkan pembentukan pembekuan darah sehingga peredaran darah menjadi lancar dan panas dari dalam tubuh dapat disalurkan ke pembuluh darah tepi. ${ }^{(4)}$ Kandungan bawang merah lainnya yang dapat menurunkan suhu tubuh adalah minyak atsiri, florogusin, sikloaliin, metilaliin, kaemferol dan kuersetin. ${ }^{(5)}$ Kandungan atsirin sebagai obat luar berfungsi melebarkan pembuluh darah kapiler dan merangsang keluarnya keringat. Baluran bawang merah ke seluruh tubuh akan menyebabkan vasodilatasi yang kuat pada kulit, yang mempercepat perpidahan panas dari tubuh ke kulit. ${ }^{(6)}$ Senyawa fitokimia flavonoid yang terdapat dalam bawang merah memiliki efek antiinflamasi dan efek antipirektik, bekerja sebagai inhibitor cyclooxygenase (COX) yang memicu pembentukan prostaglandin. Prostaglandin berperan dalam proses inflamasi dan peningkatan suhu tubuh yang akan mengakibatkan demam. Hasil studi pendahuluan pada hewan coba oleh I Gede Agus Wiryawan (2014) tentang efek ekstrak bawang merah terhadap perubahaN suhu tubuh pada tikus putih yang mengalami demam setelah diinduksi vaksin DPT 0,5 cc secara intraperitonial, menyimpulkan terdapat efek ekstrak bawang merah (allium ascalonicum L) terhadap perubahan suhu tubuh tikus putih (Rattus norvegicus) yang mengalami demam. ${ }^{(7)}$

Penelitian ini bertujuan untuk mengetahui efektifitas Ekstrak Bawang Merah (Allium Ascalonicum L) terhadap penurunkan suhu tubuh anak demam pasca imunisasi DPT Pentabio.

\section{METODE}

Jenis penelitian ini adalah eksperimen kuasi dengan rancangan pre and posttest with control group design. Pengambilan sampel dilakukan dengan metode accidental sampling. Sampel pada penelitian ini adalah bayi yang mendapat imunisasi DPT sebanyak 20 orang responden. Penelitian ini dilaksanakan mulai bulan September 2020 sampai dengan Februari 2021 di Praktik Mandiri Bidan (PMB) Istiqomah Surabaya.

Instrumen yang digunakan adalah lembar observasi untuk data tentang suhu tubuh bayi sebelum dan sesudah pemberian intervensi. Data yang telah terkumpul selanjutnya dianalisis dengan uji T. Analisis data menggunakan bantuan software SPSS for Windows versi 20.

\section{HASIL}

\section{Karakteristik Usia Responden}

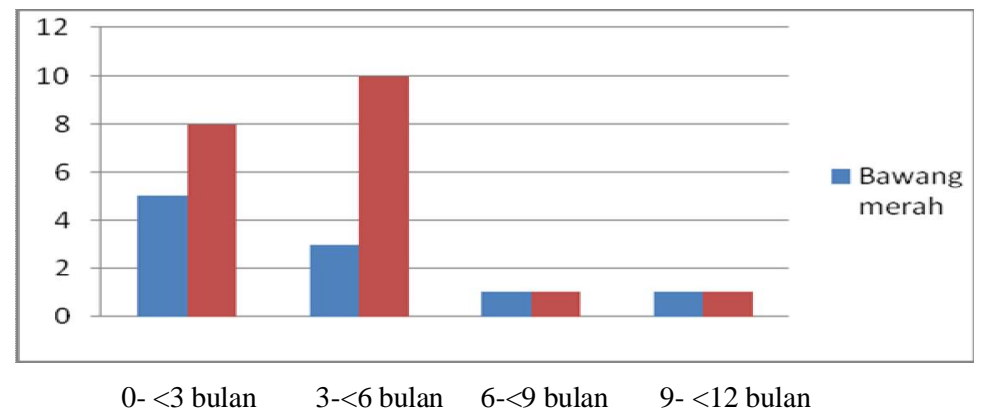

Gambar 1. Karakteristik responden berdasarkan usia pada kelompok pemberian bawang merah (Allium ascalonicum $L$ ) dan kelompok kontrol

Dari Gambar 1 dapat diketahui bahwa karakteristik responden berdasarkan usia pada kelompok pemberian bawang merah (Allium ascalonicum L) sebagian besar berusia 0 sampai kurang dari 3 bulan yaitu sebanyak 5 
orang $(25 \%)$ sedangkan karakteristik responden berdasarkan usia pada kelompok kontrol sebagaian besar berusia 3 sampai kurang dari 6 bulan yaitu sebanyak 7 orang (35\%).

\section{Karakteristik Jenis Kelamin Responden}

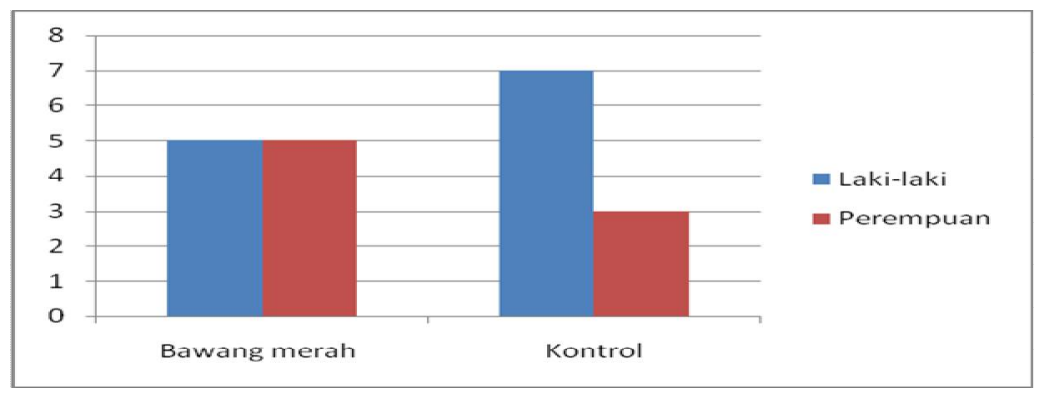

Gambar 2. Karakteristik responden berdasarkan jenis kelamin pada kelompok pemberian bawang merah (Allium ascalonicum $L$ ) dan kelompok kontrol

Dari Gambar 2 dapat diketahui bahwa karakteristik responden berdasarkan jenis kelamin pada kelompok pemberian ekstrak bawang merah (Allium ascalonicum L) prosentase laki-laki dan perempuan sama rata yaitu sebesar 5 orang $(50 \%)$ sedangkan karakteristik responden berdasarkan jenis kelamin pada kelompok kontrol sebagaian besar berjenis kelamin laki-laki yaitu sebanyak 7 orang $(35 \%)$.

\section{Hasil Pengukuran Suhu Tubuh}

Tabel 1. Distribusi suhu tubuh sebelum dan sesudah diberikan ekstrak bawang merah (Allium ascalonicum L)

\begin{tabular}{|c|c|c|c|c|c|c|c|}
\hline \multirow[t]{2}{*}{ Responden } & \multirow[t]{2}{*}{ Sebelum imunisasi } & \multicolumn{5}{|c|}{ Setelah imunisasi } & \multirow[t]{2}{*}{ Rerata setelah imunisasi } \\
\hline & & $3 \mathrm{Jam}$ & $6 \mathrm{Jam}$ & $9 \mathrm{Jam}$ & $12 \mathrm{Jam}$ & $18 \mathrm{Jam}$ & \\
\hline KP1 & 36,6 & 37,0 & 37,8 & 37,7 & 38,7 & 36,8 & 37,0 \\
\hline KP2 & 36,0 & 36,2 & 37,2 & 37,2 & 37,4 & 36,7 & 36,6 \\
\hline KP3 & 36,4 & 36,9 & 36,7 & 37,4 & 38,1 & 37,5 & 37,2 \\
\hline KP4 & 36,3 & 36,1 & 37,2 & 37,6 & 37,5 & 37,2 & 37,0 \\
\hline KP5 & 36,6 & 37,8 & 37,4 & 38,2 & 37,5 & 37,4 & 37,5 \\
\hline KP6 & 36,3 & 37,5 & 37,3 & 38,2 & 37,1 & 37,3 & 37,3 \\
\hline KP7 & 36,1 & 37,0 & 37,5 & 38,4 & 37,8 & 36,6 & 37,5 \\
\hline KP8 & 36,8 & 37,3 & 37,5 & 37,7 & 37,2 & 36,6 & 37,3 \\
\hline KP9 & 36,9 & 37,6 & 37,5 & 38,3 & 37,6 & 37,2 & 37,5 \\
\hline KP10 & 36,3 & 37,6 & 38,2 & 38,6 & 37,9 & 36,7 & 37,5 \\
\hline Rerata & 36,5 & 37,2 & 37,4 & 38,0 & 37,5 & 37,1 & 37,2 \\
\hline
\end{tabular}

Berdasarkan Tabel 1 dapat diketahui bahwa rerata suhu tubuh pada anak demam pasca imunisasi DPT Pentabio pada kelompok yang diberi ekstrak bawang merah (Allium ascalonicum L) adalah $36,5^{\circ} \mathrm{C}$; sedangkan rerata suhu tubuh pada anak demam pasca imunisasi DPT Pentabio pada kelompok yang diberi ekstrak bawang merah (Allium ascalonicum $L$ ) adalah $37,2^{\circ} \mathrm{C}$ dan mencapai puncak panas pada jam ke 9 .

Tabel 2. Distribusi suhu tubuh sebelum dan sesudah diberikan syrup Paracetamol

\begin{tabular}{|c|c|c|c|c|c|c|c|}
\hline \multirow[t]{2}{*}{ Responden } & \multirow[t]{2}{*}{ Sebelum imunisasi } & \multicolumn{5}{|c|}{ Setelah Imunisasi } & \multirow[t]{2}{*}{ Rerata setelah imunisasi } \\
\hline & & $3 \mathrm{Jam}$ & $6 \mathrm{Jam}$ & 9 Jam & 12 Jam & $18 \mathrm{Jam}$ & \\
\hline KK1 & 36,5 & 37,2 & 37,6 & 38 & 37,9 & 37,6 & 38,0 \\
\hline KK2 & 36,3 & 38,1 & 37,8 & 38,5 & 39 & 37,2 & 39,0 \\
\hline KK3 & 36,5 & 36,9 & 37 & 37,8 & 37,6 & 37 & 37,0 \\
\hline KK4 & 36,8 & 37 & 37,5 & 38,2 & 37,6 & 36,8 & 37,0 \\
\hline KK5 & 36,9 & 37,3 & 38,5 & 37,7 & 37,3 & 37 & 37,0 \\
\hline KK6 & 36,5 & 37,1 & 37,3 & 37,5 & 38 & 37,3 & 38,0 \\
\hline KK7 & 36,8 & 37,5 & 37,3 & 38,7 & 37,5 & 37,1 & 37,6 \\
\hline KK8 & 36,9 & 36,8 & 37,2 & 37,6 & 38,9 & 36,6 & 37,4 \\
\hline KK9 & 37,1 & 37,4 & 37,1 & 38,6 & 37,2 & 36,9 & 37,4 \\
\hline KK10 & 36,8 & 36,9 & 37,4 & 37,5 & 37,1 & 37 & 37,0 \\
\hline Rerata & 36,71 & 37 & 37 & 38 & 38,5 & 37 & 37,54 \\
\hline
\end{tabular}


Berdasarkan Tabel 2 dapat diketahui bahwa rerata suhu tubuh pada anak demam pasca imunisasi DPT Pentabio pada kelompok yang diberi Syrup Paracetamol adalah $36,71^{\circ} \mathrm{C}$; sedangkan rerata suhu tubuh pada anak demam pasca imunisasi DPT Pentabio pada kelompok yang diberi ekstrak bawang merah (Allium ascalonicum $L$ ) adalah $37,54^{\circ} \mathrm{C}$ dan mencapai puncak panas pada jam ke 12 .

\section{Hasil Analisa Data}

Untuk mengetahui apakah ada pengaruh pemberian ekstrak bawang merah (Allium ascalonicum L) terhadap penurunan suhu tubuh pada anak demam pasca imunisasi DPT Pentabio dilakukan uji T. Sebelumnya data terlebih dahulu dilakukan uji normalitas. Uji normalitas menggunakan uji Kolmogorov-Smirnov menghasil nilai $\mathrm{p}=0,375$ sehingga disimpulkan bahwa data berdistribusi normal, maka dapat dilanjutkan dengan uji $\mathrm{T}$.

Untuk kelompok dengan pemberian ekstrak bawang merah, hasil uji $\mathrm{T}$ menunjukkan nilai $\mathrm{p}=0,000$ sehingga disimpulkan bahwa ada perbedaan suhu badan antara sebelum dan sesudah intervensi. Untuk kelompok dengan pemberian Syrup Paracetamol, hasil uji T menunjukkan nilai $\mathrm{p}=0,000$ sehingga disimpulkan bahwa ada perbedaan suhu badan antara sebelum dan sesudah intervensi. Sementara itu, hasil uji T antara kedua kelompok menunjukkan nilai $\mathrm{p}=0,200$ sehingga disimpulkan bahwa tidak ada perbedaan penurunan suhu antara kelompok anak yang mendapatkan intervensi ekstrak bawang merah maupun syrup Paracetamol.

\section{PEMBAHASAN}

\section{Pengaruh Pemberian Ekstrak Bawang Merah (Allium ascalonicum L) terhadap Suhu Tubuh Bayi Setelah Mendapatkan Imunisasi DPT Pentabio}

Berdasarkan hasil analisis data dapat disimpulkan bahwa ada pengaruh yang signifikan dari pemberian intervensi ekstrak bawang merah (Allium ascalonicum L) terhadap suhu tubuh bayi setelah mendapatkan imunisasi DPT Pentabio. Hal ini sesuai dengan hasil penelitian yang berjudul "Pengaruh Kompres Bawang Merah terhadap Suhu Tubuh pada Pasien Demam Thypoid di RS PKU Muhammadiyah Gombong”. Hasil penelitian menunjukkan bahwa pada kelompok kompres bawang merah mempunyai rata-rata suhu tubuh sebelum diberikan intervensi adalah $37,8{ }^{\circ} \mathrm{C}$ dan setelah diberikan intervensi adalah $37,4^{\circ} \mathrm{C}$, dengan nilai signifikasi (0,000). ${ }^{(8)}$ Juga senada dengan hasil penelitian Cahyaningrum (2017) yang berjudul "Perbedaan Suhu Tubuh anak demam sebelum dan setelah Kompres Bawang Merah". Hasil penelitian menunjukkan bahwa ada perbedaan atau selisih rerata suhu sebelum dan setelah kompres bawang merah yaitu $0,734{ }^{\circ} \mathrm{C}$ dengan nilai signifikan $(\mathrm{p}=0,000)$ sehingga disimpulkan bahwa terdapat perbedaan suhu tubuh yang bermakna antara sebelum dan setelah kompres bawang merah ${ }^{(5)}$, demikian pulan hasil penelitian Cahyaningrum, et al. (2013) yakni ada pengaruh kompres bawang merah terhadap suhu tubuh anak demam dengan signifikasi ( $p$ value 0,000). Hasil penelitian tersebut menunjukkan bahwa pada kelompok perlakuan dengan kompres hangat mempunyai rerata penurunan suhu sebesar $0,976^{\circ} \mathrm{C}(\mathrm{S} . \mathrm{D} \pm 0,3270)$ sedangkan pada kelompok kompres bawang merah rerata penurunan suhu sebesar $1,106^{\circ} \mathrm{C}(\mathrm{S} . \mathrm{D} \pm 0,3699) .{ }^{(2)}$

Bawang merah merupakan ramuan pengobatan herbal untuk menurunkan demam pada anak. Bawang merah mengandung botani yang berguna untuk memberikan efek yang dapat mengeluarkan keringat dan pendingin pada tubuh. Santich dan Bone juga menyatakan bahwa penggunaan bawang merah juga digunakan sebagai pengobatan tradional Cina untuk menurunankan demam, hal tersebut dikarenakan bawang merah memberikan ekspresi panas dalam menanggapi sebuah patogen eksternal sehingga dapat menghilangkan kelebihan panas. ${ }^{(12)}$ Tusilawati menyatakan bahwa umbi bawang merah memiliki kandungan yang mengobati demam dan melancarkan peredaran darah antara lain: floroglusin, sikloaliin, metialiin, dan kaemferol. ${ }^{(9)}$ Pemberian bawang merah yang semakin banyak dapat menurunkan suhu tubuh semakin cepat sehingga lebih efektif. (10)

\section{Pengaruh Pemberian Intervensi Syrup Paracetamol Terhadap Suhu Tubuh Bayi Setelah Mendapatkan Imunisasi DPT Pentabio}

Berdasarkan hasil analisis data dapat disimpulkan bahwa ada pengaruh yang signifikan pemberian intervensi syrup Paracetamol terhadap suhu tubuh bayi setelah mendapatkan imunisasi DPT Pentabio. Pada saat terjadi demam paracetamol merupakan obat antipiretik yang disarankan oleh dokter atau petugas kesehatan lainnya. Keuntungan lain dari paracetamol tidak menimbulkan efek yang mengiritasi lambung, gangguan pernafasan, dan gangguan keseimbangan asam basa. Kerugian penggunaan dari paracetamol jangka panjang dapat menimbulkan efek toksik sehingga berakhibat terhadap kerusakan hepar. ${ }^{(11)}$ 
Obat antipiretik dapat menginhibisi laju ekspresi dari siklooksigenase-2 (COX-2) dan Biosintesis PGE2 untuk mengurangi suhu tubuh. Terdapat agen-agen sintesis ireversibel yang merupakan inhibitor siklooksigenase-2 (COX-2) dengan selektifitas yang begitu tinggi akan tetapi dapat menimbulkan efek racun bagi sel - sel hati, glomeruli, korteks otak dan otot jantung. Akan tetapi natural iklooksigenase-2 (COX-2) inhibitor memiliki selekstifitas yang lebih rendah dengan kemungkinan timbulnya efek samping yang lebih sedikit. Untuk menghambat pengeluaran dari pro-inflammatory mediator sejumlah tanaman ekstraksi sudah di teliti memiliki tujuan untuk memodulasi jalur siklooksigenasi yang akan menginhibisi leukotriene dan sintesis prostaglandin oleh inhibisi siklooksigenase -1 (COX-1) dan siklooksigenase-2 (COX-2). ${ }^{(8)}$

\section{Perbedaan Pemberian Intervensi Ekstrak Bawang Merah (Allium ascalonicum L) dan Syrup Paracetamol terhadap Suhu Tubuh Bayi Setelah Mendapatkan Imunisasi DPT Pentabio}

Berdasarkan hasil analisis data didapatkan bahwa tidak ada perbedaan penurunan suhu antara kelompok anak yang mendapatkan intervensi ekstrak bawang merah maupun syrup Paracetamol. Hal ini senada dengan penelitian Cahyaningrum, et al. (2014) dengan judul "Perbedaan Kompres Hangat dan Kompres Bawang Merah terhadap Penurunan Suhu Tubuh Anak dengan Demam”. Hasil penelitian menunjukkan bahwa pada pada kelompok kompres hangat rerata penurunan suhu sebesar $0,976^{\circ} \mathrm{C}(\mathrm{S} . \mathrm{D} \pm 0,3270)$ sedangkan pada kelompok kompres bawang merah rerata penurunan suhu sebesar $1,106^{\circ} \mathrm{C}(\mathrm{S} . \mathrm{D} \pm 0,3699)$. Perbedaan rerata penurunan suhu antara kedua kelompok sebesar $0,1294^{\circ} \mathrm{C}(95 \%$ CI - 0,3733-0,1145). Hasil Uji t tidak berpasangan diperoleh nilai signifikansi 0,288 . Kesimpulannya tidak terdapat perbedaan rerata selisih suhu yang bermakna antara kelompok kompres hangat dengan kelompok kompres bawang merah, namun pemberian kompres bawang merah lebih cepat mencapai suhu normal dibanding dengan pemberian kompres hangat. ${ }^{(13)}$

Suhu tubuh diatur seluruhnya oleh mekanisme persarafan umpan balik, dan hampir semua mekanisme ini terjadi melalui pusat pengaturan suhu yang terletak di hipotalamus. Saat ada pirogen, menyerang tubuh maka akan terjadi mekanisme pembentukan antibodi terhadap pirogen tersebut. Hal ini merangsang sitokin-sitokin yang bekerja sebagai mediator proses imun baik lokal maupun sistemik. Sitokin ini yang memicu pelepasan asam arakidonat Kemudian asam arakidonat selanjutnya dengan bantuan enzim siklooksigenase diubah menjadi prostaglandin. Adanya peningkatan prostaglandin terutama pada daerah preoptik hipotalamus anterior akan menyebabkan peningkatan suhu pada pusat thermoregulasi di hipotalamus, sehingga tubuh akan mengikuti thermostat untuk meningkatkan suhu sampai terjadi demam. ${ }^{(14)}$

Penatalaksanaan demam terdiri dari dua macam yaitu pemberian terapi farmakologi dan non farmakologi. Pada penelitian ini pemberian terapi farmakologi diberikan berupa syrup paracetamol. Paracetamol sebagai terapi pilihan lini pertama pada anak untuk pengobatan demam kurang dari $41^{\circ} \mathrm{C}$ dan sakit ringan sampai sedang. Parasetamol telah tersedia tanpa resep sejak tahun 1960 dan mempunyai keamanan pada penggunaan jangka pendek. Parasetamol diakui sebagai salah satu obat yang paling umum digunakan yang merupakan golongan non-opioid. ${ }^{(15)}$ Parasetamol mempunyai profil efikasi yang bagus, profil reaksi obat yang merugikan sangat rendah dan sangat rendah pula potensi berbahaya dari interaksi obat-obatnya. ${ }^{(16)}$

Selain penggunaan obat anti piretik, penurun suhu tubuh dapat dilakukan pemberian non farmakologi salah satunya berupa ekstrak bawang merah. Bawang merah mengandung asam glutamate yang merupakan natural essence (penguat rasa alamiah), terdapat juga senyawa propil disulfide dan propil metal disulfide yang mudah menguap dan baluran bawang merah keseluruh tubuh akan menyebabkan vasodilatasi yang kuat pada kulit, yang memungkinkan percepatan perpindahan panas dari tubuh ke kulit. Gerusan bawang merah dipermukaan kulit membuat pembuluh darah vena berubah ukuran yang diatur oleh hipotalamus anterior untuk mengontrol pengeluaran panas, sehingga terjadi vasodilatasi (pelebaran) pembuluh darah dan hambatan produksi panas. Darah didistribusi kembali ke pembuluh darah permukaan untuk meningkatkan pengeluaran panas. Terjadinya vasodilatasi ini menyebabkan pembuangan panas melalui kulit meningkat, pori-pori membesar, dan pengeluaran panas secara evaporasi (berkeringat) yang diharapkan akan terjadi penurunan suhu tubuh mencapai keadaan normal kembali. ${ }^{(17)}$

\section{KESIMPULAN}

Berdasarkan hasil penelitian disimpulkan bahwa pemberian ekstrak bawang merah dan Syrup Paracetamol efektif untuk menurunkan suhu suhu tubuh anak demam pasca imunisasi DPT Pentabio.

\section{DAFTAR PUSTAKA}

1. Kemenkes RI. Peraturan Menteri Kesehatan Republik Indonesia Nomor 42 tahun 2013 tentang penyelenggaraan imunisasi. Jakarta: Kemkes RI; 2013. 
2. Cahyaningrum ED, Putri D. Perbedaan Suhu Tubuh Anak Demam Sebelum dan Setelah Kompres Bawang Merah. MEDISAINS (Jurnal Ilmiah Ilmu-Ilmu Kesehatan). 2017;15(2):68-74.

3. Soedibyo S, Souvriyanti E. Gambaran Persepsi Orang Tua tentang Penggunaan Antipiretik sebagai Obat Demam. Sari Pediatri. 2006;8:142-146.

4. Suryono, Sukatmi, Jayanti TD. Efektifitas Bawang Merah terhadap Penurunan Suhu Tubuh pada Anak Febris Usia 1-5 Tahun. Jurnal AKP. 2012;6:63-68.

5. Cahyaningrum ED. Pengaruh Kompres Bawang Merah terhadap Suhu Tubuh Anak Demam. Jurnal Publikasi Kebidanan Akbid YLPP Purwokerto. 2017: 8089.

6. Harianah A, Megawati. Perbedaan Efektifitas Pemberian Kompres Hangat dan Kompres Bawang Merah Terhadap Penurunan Suhu Tubuh Anak Usia 0-1 Tahun yang Mengalami Demam Pasca Imunisasi DPT di Desa Semboro. Jurnal Kesehatan dr. Soebandi. 2014;5(1);329-333.

7. Wiryawan IGA. Efek Ekstrak Bawang Merah (Allium ascalonicum L.) terhadap Perubahan Suhu Tubuh Pada Tikus Putih (Rattus norvegicus) yang Mengalami Demam. Coping: Community of Publishing in Nursing. 2015; 3 (1).

8. Golam A, Shibly N, Amun A. Phytochemical Screening and Antipyretic Effect of Curcuma zedoaria Rosc. (Zingiberaceae) Rhizome. Bashundhara, Science domain international. 2014;569-573.

9. Harianah A, Megawati. Perbedaan efektivitas pemberian kompres hangat dan kompres bawang merah terhadap penurunan suhu tubuh anak usia 0-1 tahun yang mengalami demam pasca imunisasi DPT di Desa Semboro. Jurnal Kesehatan dr. Subandi. 2018;5(1):329-333.

10. Rachmad, Suryani S, Gareso PL. Penentuan Efektifitas Bawang Merah dan Ekstrak Bawang Merah (Allium Cepa var. ascalonicum) dalam Menurunkan Suhu Badan. Makassar: Program Studi Fisika, Jurusan Fisika, Fakultas MIPA, UNHAS; 2012.

11. Queensland Government. Queensland Health, Fever [Internet]. 2015 [cited 2020 Jul 1]. Available from: http://access.health.qld.gov.au/hid/ChildHealth/InfectionsandParasites/fever_is.asp

12. Santich R, Bone K. Infeksi Masa Kanak-kanak Umum dan Manajemen Demam. In: Phytotherapy Essentials: Anak Sehat Mengoptimalkan Kesehatan Anak dengan Herbal Warwick. Australia Phytotherapy Pers; 2018.

13. Cahyaningrum ED, Anies, Julianti HP. Perbedaan Kompres Hangat dan Kompres Bawang Merah terhadap Penurunan Suhu Tubuh Anak dengan Demam. Bhamada Jurnal Ilmu dan Teknologi Kesehatan. 2014;5(1).

14. Breivik H. Postoperative Pain: towards Optimal Pharmacological and Epidural Analgesia In: Giamberardino M.A (Ed.) An Updated Review: Refresher Course Syllabus, Seattle (WA). IASP Press; 2012:337-349.

15. Prescott LF. Paracetamol: Past, Present, and Future. Am. J. Ther., 2002;7(2):143-147.

16. Kurniati CH, Azizah AN. Pemanfaatan Obat Herbal Penurun Panas Pada Balita Sakit di Desa Kaliurip Kecamatan Purwojati Kabupaten Banyumas. The $8^{\text {th }}$ University Research Colloquium: 2018.

17. Setiana E. Pengaruh Kompres Bawang Merah TerhadapPenurunan Suhu Tubuh Anak Demam. Purwokerto: Repository Universitas Muhammadiyah; 2020. 